\title{
Institutional Principles of Building the Fiscal Mechanism for Regulating the Investment Development of the National Economy
}

\author{
By Viktoriia Rudenko ${ }^{1}$, Ruslan Voloshchuk ${ }^{2}$, Roman Shchur ${ }^{3}$, Volodymyr Matskiv ${ }^{4}$
}

\begin{abstract}
The state, influencing the processes of organization of fiscal relations by forming institutions, directs the established fiscal relations, manages the channels and directions of fiscal flows, clarifies the proportions of financial resources distribution and thus regulates the investment development of the economy. Therefore, the aim of the study is to determine the institutional principles for building a fiscal mechanism, from which depends not only its effective functioning, but also the impact on investment processes in the national economy. In order to substantiate the institutional principles of building a fiscal mechanism for regulating the investment development of the national economy, general and special research methods were used (analysis and synthesis, induction and deduction, abstraction, analogy, theoretical generalization, etc.). The historical development of institutional theory is considered in the course of the research. Approaches to the interpretation of the meaning of "institution" concept are defined, their functions and characteristics are outlined. The essence and components of the institutional structure of the fiscal mechanism for regulating the investment development of the national economy are substantiated. As a result of the research it is proved that the institutional structure of the fiscal mechanism is four-level and includes the cognitive level, regulatory level, organizational level, resource-technological level. It is determined that at the present stage of development of Ukraine the institutional structure of the fiscal mechanism is formed, but its characteristics do not sufficiently correspond to the features, resources and tasks of regulating the investment development of the national economy.
\end{abstract}

Keywords: fiscal policy, fiscal mechanism, investment development, institutionalism

\section{Introduction}

Modern processes of fiscal policy development and implementation have brought up the issues of institutional aspects of the functioning of the fiscal mechanism for regulating the investment development of the national economy, because at the institutional level norms, values, stereotypes, ideas, behavior are formed and changed, the change of which leads to global consequences. The functioning of institutions explains the situation in which, with equivalent processes in the economic systems of different countries with the use of universal technologies of reforming and modernizing the

| ${ }^{1} \mathrm{PhD}$ (Economics), Doctoral student of the Department of Finance, Kyiv National Economic University named after Vadym Hetman, Ukraine

${ }^{2} \mathrm{PhD}$ (Economics), Senior Lecturer of the Department of Finance, Banking and Insurance, Vinnitsia educational and scientific institute of economics WUNU, Ukraine

${ }^{3}$ Doctor of Economics, Professor of the Department of Finance, Vasyl Stefanyk Precarpathian National University, Ukraine

${ }^{4} \mathrm{PhD}$ (Economics), Lecturer of the Department of Finance, Vasyl Stefanyk Precarpathian National University, Ukraine 
economy, fundamentally different results of innovations are recorded. That is, the effectiveness of fiscal policy depends crucially on the institutions that regulate the life of society as a whole. And whatever the views of scientists were on the nature and conditions of institutions' occurrence, it must be recognized that they have an undeniable influence on the fiscal mechanism for regulating the investment development of the national economy.

Considering the institutional principles of the fiscal mechanism for regulating the investment development of the national economy is stipulated by a number of reasons identified by Vahtina (2005, pp. 24-25), among which:

1) regulation of the economy not only by economic laws, but also by the actions of people, in the desire and choice of which is always embodied a certain set of economic expectations, social norms, cultural attitudes and ethical ideas;

2) the growing attention of economics to a human, because its psychological, social and spiritual characteristics have a growing influence on the processes of management;

3) a change in the ratio between sectors of the economy towards the sector of intangible production, which operates at the expense of human capabilities.

The institutional foundations of the fiscal mechanism for regulating the investment development of the national economy are due to the existence of an institutional direction in economic theory, which emerged as a reaction at the non-historical and orthodox neoclassical economic theory, on the one hand, and on the other, - at the attempt to justify the dominance of institutions in socio-economic life of society.

Institutionalism originated in the late XIX - first half of XX century in the United States. For the first time in 1918 Hamilton (1919) introduced the terminology of institutional economic theory in his paper "The Institutional Approach to Economic Theory". The scientist substantiated five criteria, the observance of which makes it possible to attribute institutionalism to the directions of economic theory. Such criteria include:

1) unification of economic science;

2) compliance with modern regulatory problems;

3) presence of its own subject of study;

4) connection with the content of processes;

5) based on an acceptable theory of human behavior (Hamilton, 1919, pp. 312-316).

Taking into account the criteria of Hamilton (1919), it can be argued that it is institutionalism itself that allows to unify economics and form the basic principles of specialized research. It is institutionalism that gathers facts and formulates the principles necessary for a sensible approach to solving regulatory problems. In addition, institutionalism is associated with processes of change in the nature and / or functions of the institutions that shape the economic system of society. Finally, institutionalism is a behavioral science and is based on the theory of motives of social psychology, exploring how the behavior of the individual is influenced by the institutions, in conditions of which he tries to ensure his personal interest.

The period of 20-30-ies of the twentieth century is called the period of early traditional institutionalism, which is represented by the works of Mitchell (1910), Hamilton (1919), Veblen (1922), Clark (1923), Commons (1931), Ayres (1944) and others. In the works of these scientists, the economy is focused on learning, limited rationality and evolution (rather than assuming stable advantages, optimality and balance). Early traditional 
institutionalism emphasizes the need for a deeper study of institutions and views economics as the result of the complex interaction of different institutions. In the postwar years there was a modern traditional institutionalism, represented by the works of Heilbroner (1953), Myrdal (1957), Perroux (1960), Fourastie (1960), Galbraith (1967), Hodgson (2006) and others, who categorically rejected the methodological basis of classical and neoclassical theories. They considered economics in the humanities, natural sciences, and historical sciences, insisting that it should interpret economic activity rather than seek any universal laws and use formal methods of the exact sciences. Within its framework, there are no constructions of ideal economic systems, and existing institutions are compared in reality not with the ideal, but with each other.

At the scientific and methodological level, traditional institutionalism is manifested in the provisions identified by Kovalenko (2011), namely:

1) dissatisfaction with the general neoclassical approach to economics, where the methodology of universality based on abstract and extremely rational assumptions prevails; 2) the desire to integrate economic knowledge with other social sciences, the methodology of which expands the possibilities for the theoretical description of economic systems;

3) the desire to overcome the underestimation of the influence of historical factors on the development of economic processes and to be based on the study of real forms of economic life in their specific empirical and national certainty;

4) recognition of the need to transform the economic system through active social control over business (p. 58).

Despite the decline in the popularity of institutionalism after the development of Keynesian doctrine, in the second half of the twentieth century began to revive interest in some aspects of this area of economic theory. With new developments in the economic theory of organizations, information, property rights and transaction costs, an attempt was made to integrate institutionalism into the latest developments in economics, which manifested itself in the emergence of a new institutional economic theory. This direction was first proclaimed in 1975 in the work of Williamson (1975) Markets and Hierarchies: Analysis and Anti-Trust Implications, A Study in the Economics of Internal Organization. Representatives of the new institutional economic theory such as Williamson (1975), North (1990), Ostrom (1990), Coase (1992), Eggertsson (2003), Stiglitz and Walsh (2006), Olsen (2007) and others used neoclassical theory to explain areas of human society that are usually considered outside the scope of economic theory. These scientists tried to expand the boundaries of the economy, focusing on the institutions that underlie economic activity. However, later the new institutional economic theory moved away from both the basic neoclassical theory and the traditional institutional theory. Its representatives replaced the attempt of traditional institutionalists to use the history and study of institutions to explain economic behavior with an attempt to use neoclassical theory to explain history, social relations, and the formation of institutions.

Institutionalism in its modern modification is characterized by its flexibility and lack of orthodoxy. It affirms the idea that over time, any institutions are replaced by new ones, based on the expediency of reaching a consensus between the stakeholders involved in the relevant interactions. On the other hand, institutionalism is based on an interdisciplinary approach, which determines its ideological diversity and generates a number of internal contradictions. Institutionalists, choosing certain methodological tools, usually fall under 
the influence of philosophical, sociological, political, legal, psychological, economic and other components of scientific research, which leads to conceptually different results, in particular in defining the main categories of institutional theory.

\section{Literature Review}

Institutionalism as a branch of economic theory explores the role of institutions in influencing the economic behavior of individuals. It is based on the concept of "institution", which comes from Latin "institutio" - instruction (Melnychuk, 1974, p. 336). It should be noted that among institutionalists there are several approaches to the interpretation of the institution essence, which causes uncertainty in the content of derived concepts and often creates ambiguity in the understanding of what is said. In addition, translation problems have led to discussions among Ukrainian scholars about the appropriateness of using the term "institution" or replacing it with a definition of "institute" derived from Latin "institutum" - device, institution (Melnychuk, 1974, p. 336). For the purposes of the study, we will use the term "institution", because institutional scientists used the term "institution" and not "institute".

At present, within modern institutionalism, there are many interpretations of the definition of "institution", which can be reduced to three concepts identified by Hindriks and Guala (2015, p. 460): institutions based on rules, institutions as a balance in strategy games and philosophical interpretation of institutions as a system of constitutional rules. However, the study of the original works of institutional scientists has allowed us to identify a number of other approaches to the definition of "institution".

1. The ethical approach considers the institution as a certain ethical (moral, value) position of a human, which influences his choice of one alternative behavior from the set of available alternatives. This approach was supported by Hamilton (1919), who defined institutions as "merely conventional methods of behavior on the part of various groups or of persons in various situations" (p. 316). Veblen (1922) called institutions "special methods of life and of human relations" (p. 188), or "prevalent habits of thought with respect to particular relations and particular functions of the individual and of the community" (p. 190). Perroux (1960) described institutions as "long-lasting settings of action, long-lasting rules of the social system, and collective habits" (p. 118). Hodgson (2006) covered institutions as "systems of established and embedded social rules that structure social interactions" (p. 18). Parkinson and Noble (2008) interpreted institutions as "custom or system that has existed for a long time among a particular group of people" (p. 286). Without underestimating the contribution of these scholars to the theory of institutionalism, we believe that in addition to the ethical views of the individual, his choice is influenced by a number of other factors. After all, although the ethical position of the individual is, in fact, his internal constraint in the choice of behavior, but it is impossible not to take into account the norms of behavior imposed on him by the external environment, as well as the presence of organizations that ensure their implementation.

2. The normative approach defines institutions as externally imposed rules governing human behavior. Thus, Commons (1931) interpreted institutions as "framework of laws or natural rights within which individuals act like inmates", or "the behavior of the inmates themselves", and "collective action in control, liberation and expansion of individual 
action" (p. 648). Ostrom (1990) described the institutions as "the sets of working rules that are used to determine who is eligible to make decisions in some arena, what actions are allowed or constrained, what aggregation rules will he used, what procedures must be followed, what information must or must not be provided, and what payoffs will be assigned to individuals dependent on their actions" (p. 51). Eggertsson (2003) defined institutions as "sets of rules governing interpersonal relations, noting that we are talking about formal political and organizational practices" (p. 70). Searle (2005) described institutions as "ny collectively accepted system of rules (procedures, practices) that enable us to create institutional facts" (p. 21). Brousseau and Glachant (2008) characterized the institutions as "tools built by humanity to coordinate, despite the inability of human beings to be perfectly rational", as well as "tools built to overcome the cognitive limits of human beings" (p. XLV). Paying tribute to the research of these scientists, we want to note that to consider the institution as some external restrictor of human freedom of choice is debatable. Thus, legally established rules of conduct are usually generated by ethical norms in the course of the culture of society development, and without organizations that ensure their implementation, such norms will not be effective.

The separation of ethical and normative approaches is conditional. After all, as North (1990) noted, the difference between informal and formal rules is determined by the position in the hierarchy of rules, not by the essence. Together they form a continuous set of rules - from taboos, customs and traditions at the one end to written constitutions at the other (p. 46).

3. The game approach treats institutions as the rules of a particular game that an individual plays with other individuals. This approach was developed by North (1990), who outlined the institutions as "the rules of the game in a society or, more formally, are the humanly devised constraints that shape human interaction, and in consequence they structure incentives in human exchange, whether political, social, or economic" (p. 3). Rutherford (1994) defined institutions as "a regularity of behaviour or a rule that is generally accepted by members of a social group, that specifies behaviour in specific situations, and that is either self-policed or policed by external authority" (p. 182). Aoki (2000) argued that institutions are "a self-sustaining system of collectively shared beliefs about nontechnological, self-enforcing rules of the game that govern the strategic interactions of the agents" (p. 57). Bowles (2004) interpreted institutions as "the laws, informal rules, and conventions that give a durable structure to social interactions among the members of a population" and claimed that "an institution may be formally represented as a game" (pp. 47-48). Olsen (2007) characterized the institutions as "an enduring collection of rules and organized practices, embedded in structures of meaning and resources that are relatively invariant in the face of turnover of individuals and changing external circumstances" (p. 3). Noting the significant contribution of these scholars to the theory of institutionalism, we want to emphasize that to consider institutions solely as rules of the game, balance or common beliefs that motivate equilibrium, is also debatable. Thus, any game is provided not only by rules, but also by players, which supporters of the game approach refer to the concepts of "institute" or "organization", and not to the term "institution".

4. The organizational approach characterizes institutions as a form of internal order, coherence of interaction of individual parts of the social environment. Thus, Knight (1921) 
viewed the institution as "special phenomena arising from the tendency to deal with uncertainty by consolidation" (p. 245). Stiglitz and Walsh (2006) understood institutions "organizations, which raising funds (and sharing and insuring risk), including banks and insurance companies" (p. 16) and "organizations, which ensure that a cooperative outcome is reached, in particular the World Trade Organization" (p. 322). Hodgson (2009) described institutions as "structures that constrain, influence and enable individuals" (p. 9). Samuelson and Nordhaus (2010) defined institutions as "organizations, which promote peace and economic prosperity through cooperative policies" (p. 359), as well as "organizations, which carry out the financial decisions of households, businesses, and governments" (p. 454). Taking into account the position of these scientists, we believe that to consider institutions as organizations (institutions) that provide a compromise between individuals, means to narrow their content. After all, a compromise between economic agents is achieved, first of all, due to the rules, the implementation of which is entrusted to various organizations. In addition, this approach identifies two concepts - "institutions" and "institutes", although, in our opinion, the first definition is much broader than the second.

5. The comprehensive approach treats institutions as a set of rules and organizations that ensure their implementation. A supporter of this approach is Hamilton (1919), who considered the institution as "such elements of life and directive agencies" (p. 313). Schmoller (1900) defined institutions as "a set of formal and informal rules, including institutes that enforce them" (p. 61). Zaslavskaja (2004) considered institutions as "formal legal norms, informal socio-cultural norms, formal organizations that monitor compliance with norms, and public organizations that perform the same functions" (p. 114). Greif and Kingston (2011) described institutions as "system of "institutional elements", particularly beliefs, norms, and expectations that generate a regularity of behavior in a social situation" (p. 26). Kolodko (2006) included in the institutions:

the procedures and rules of conduct sanctioned by the law or by custom; the applicable laws and regulations, promulgated in order to protect the interests of market entities; the organizations and administrative/political structures that serve the needs of various market entities; market culture and mentality (p. 10).

In our opinion, it is a comprehensive approach that most fully takes into account the versatility and depth of the concept of "institution" and will be used in the study.

In general, all the above mentioned approaches to defining the essence of the concept of "institution" are related to the influence of rules (formal and informal) and organizations on the interaction between economic agents. Therefore, through the development of institutions, society expands the boundaries of social and economic interactions.

\section{Methodology and Research Methods}

The research methodology is based on dialectical, systemic and structural approaches, according to which the institutional structure of the fiscal mechanism for regulation the investment development of the national economy is considered in inseparable connection and causality.

In the process of studying the theory of institutionalism, general scientific and special research methods were used. Interpretation of the main categories "institution" and 
"institutional structure" is based on the use of methods of analysis and synthesis, induction and deduction, abstraction, analogy, theoretical generalization. The study uses systemfunctional, functional-structural, complex, comparative and graphic methods, which explain the functioning of the institutional structure of the fiscal mechanism for regulating investment development.

\section{The Aim of the Study}

The purpose of the research is to determine the economic content and specific characteristics of the fiscal mechanism for regulating the investment development of the national economy.

\section{Results}

According to the comprehensive approach as the institutions in the fiscal mechanism for regulation the investment development of the national economy, we consider a set of rules of conduct and organizations that influence the formation, distribution and use of financial resources to implement fiscal policy aimed at changes in the national economy, due to the implementation of investment activities, as a result of which benefits are obtained and the interests of all subjects of economic relations are satisfied, as well as a new qualitative state of the economy arises.

Researchers (Borovskaja, 2018, p. 6; Martjukova, 2012, p. 89) have concluded that any institution should include a number of interrelated elements, including:

- the situation that determines the conditions in which the institution operates;

- individual (addressee of the institution), i.e., a person whose actions fall under the regulation of the institution;

- action assigned, prohibited or permitted by the institution (content of the institution);

- sanctions for non-compliance with the rule by the addressee, i.e., actions to be taken in case of non-compliance or improper performance of the institution;

- the guarantor of the institution (organization), i.e., the entity that is endowed with the functions of coercion to perform the institution or punishment for its violation.

The essence of institutions is revealed in their functional purpose. Although there is no unity among scientists in the specification of the functions of institutions, but the analysis of their work (Agapova, 2006, p.10; Panov, 2011, p. 19; Shapkin, 2011, p. 59; Cherkas, 2010, p. 225-227) has allowed us to identify such:

1) coordination, which consists in minimizing efforts to find contractors and reach agreements by forming a predictable and relatively secure information environment, in particular in counteracting opportunistic behavior, i.e., the behavior of individuals in accordance with their own interests and unlimited morality;

2) cooperative, which involves reducing uncertainty in the face of incomplete information by ensuring mutual understanding between individuals, which is expressed in the formation of agreed expectations with minimal information exchange;

3) regulatory, aimed at influencing individuals in order to reduce the harm they cause to each other or its compensation, in particular the determination and regulation of both direct individual experience and social practice of people in general; 
4) distributive, which consists in ensuring the adoption of a specific decision on the coordination of activities of individuals, which establishes inequality (or equality) between them in terms of ownership / management of resources and technologies for their processing;

5) information, characterized by the transfer of information and organization of training, which ensure the inheritance of institutions.

Each of the functions of institutions, as noted by Cherkas (2010, pp. 227-228), performs its clearly defined role in the economy. Thus, the coordination function establishes interaction between individuals and ensures that they make informed decisions, which allows to accelerate the implementation of economic operations; the cooperative function defines the limits of rational behavior and reduces uncertainty, which increases the efficiency of the national economy as a whole; the distributive function of institutions determines the limits of permissible economic actions for individuals, gives them a certain set of rights in relation to each other, which contributes to the economic efficiency of all market participants and maximize benefits; the regulatory function helps to increase the level of economic security through risk insurance; information function provides individuals with the necessary information and knowledge to make effective management decisions.

Aoki (2000) identified the characteristics of institutions, which included:

endogeneity (through self-preservation, self-sufficiency and reproduction), information compression (due to limited representation), resistance to constant changes in the environment and small deviations (due to invariant features of the equilibrium course, perception by almost all agents and reproduction in a constantly changing environment), universality of relevance (through joint regulation of strategic interaction of agents and perception by all agents), and multiplicity (p. 57).

These features characterize institutions as a specific economic category that unites individuals, rules and organizations into a single structure.

It is worth saying that individuals accept institutions if they meet certain principles. And such principles can have absolutely different nature. Dequech (2013) distinguished three groups of principles, based on which institutions can be adopted. This is moral, political and epistemological legitimacy (Dequech, 2013, p. 95). In this context, legitimacy is understood as consistency with certain values. Legitimate is the institution that is considered correct in accordance with accepted in society specific values. Legitimate can be those institutions that, even after being criticized, are still considered suitable and correct. Moral legitimacy is correlated with the values of honesty, justice, integrity, and so on. Political legitimacy, which is often associated with formal institutions, often appeals to moral values that take on a political dimension. Such values include democracy, freedom, equality, social justice, and so on. Epistemological legitimacy presupposes the existence of confirmation that one or another phenomenon is well researched and studied, it has a concrete empirically substantiated confirmation. Epistemological values are cultivated in the academic environment, but politicians, public figures and producers of goods also often refer to them, usually distorting them.

North (1990) noted that "institutions create a structure for exchange that, together with the technology used, determines transaction and transformation costs" (p. 34). Based on this, the institutional structure of the fiscal mechanism for regulating the investment 
development of the national economy is a set of interrelated formal and informal rules, as well as organizations that ensure their implementation, which together influence the formation, distribution and use of financial resources to implement fiscal policies aimed at changes in the national economy, due to the implementation of investment activities, and as a result, the benefits are obtained and interests of all subjects of economic relations are satisfied, and a new qualitative state of the economy emerges.

In our opinion, the institutional structure of the fiscal mechanism for regulating the investment development of the national economy should be presented in the form of a multilevel pyramid, which is presented in Fig. 1.

We believe that there descending and ascending links between the levels of the institutional structure of the fiscal mechanism for regulating the investment development of the national economy. When considering descending links, informal rules define the formal ones within which organizations operate that control resource-technological financial flows. Thus, the multifaceted and versatility interaction of economic agents is determined by spiritual values, cultural traditions, cognitive abilities, worldview, well-being of economic agents, i.e., informal rules. Formal rules always depend on informal rules. If the regulations are not familiar and embodied in individual dispositions, then their formality will not have a significant impact. It will simply be declarations or proclamations, not effective rules. Organizations are created on the basis of formal and informal rules and produce or enforce them. Management of financial resources due to various technologies is carried out by authorized organizations on the basis of formal and informal rules. Ascending from the resource-technological level, signals are sent to organizations that help them adjust their decisions, which are a manifestation of their power. Using their power, organizations also try to change the formal rules in their favor. Finally, the problems that arise in organizations when applying formal rules can cause value transformations, i.e. changes in informal rules.

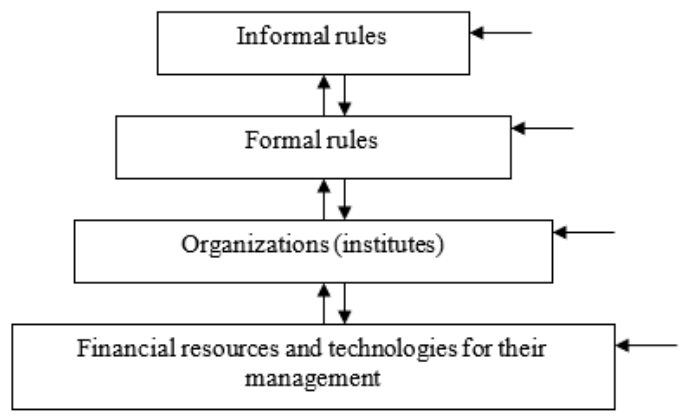

Cognitive level

Regulatory level

Organizational level

Resource and technological level

Figure. 1: Institutional structure of the fiscal mechanism for regulating the investment development of the national economy

Source: Own elaboration

Vanberg (1994) believes that the rules of conduct lying at the heart of institutions are divided into inherited, genetically transmitted and acquired, transmitted through culture. The latter, in turn, can be divided into personal and social, and social rules - into informal (enshrined in custom) and formal ones (enshrined in law) (Vanberg, 1994, p. 110). North (1990) similarly distinguishes between informal restrictions (customs and codes of 
conduct) and formal restrictions (rules invented by people) (p. 4). Menger (1985) argues that the rules according to formation are divided into pragmatic (are the result of a general expression of will aimed at their establishment) and organic (are an unintentional result of human efforts to achieve individual goals) (pp. 146-147). In fact, pragmatic rules are formal, while organic rules are informal.

Based on the mentioned above, at the cognitive level of the institutional structure of the fiscal mechanism for regulating the investment development of the national economy are situated informal rules, characterized by the lack of strict regulation of behavior of individuals, forms and methods of activity and sanctions for misconduct. Informal rules are habits, customs, beliefs, mentality, inner beliefs, generally accepted conventions, which are the result of close coexistence of individuals, the guarantor of which is any individual who has noticed their violation. Such rules, although they are rather strict restrictions on the behavior of individuals, but are usually not recorded in writing and are protected by specific mechanisms of their self-support, which do not require the maintenance of a specialized body to ensure their implementation. According to Agapova (2006), this is due to the fact that, emerging as a means of coordinating persistent forms of human behavior, informal rules become not only socially sanctioned norms, but also internally binding standards of behavior for individuals. The latter occurs when addictive rules begin to function as principles of motivation and attitudes that are followed by people (Agapova, 2006, p. 12).

Informal rules are characterized by maximum personification, low imperativeness, general wording, significant inertia, less controllability, variability and maneuverability, as well as the absence of severe sanctions for their violation. The advantages of informal rules include, first, the ability to adapt to changing external conditions, transformations within society and other exogenous or endogenous changes. Secondly, the possibility of applying different sanctions in each case (from a rather severe warning to exclusion from the social group). Disadvantages of informal institutions include ambiguity in the interpretation of rules (in the context of interaction of individuals of different cultures, different experiences, and information asymmetry), low effectiveness of sanctions (in terms of leveling moral principles and ethical norms by individuals and assessing the probability of punishment as insignificant compared to benefits from deviant behavior), the emergence of discriminatory rules against certain social groups, as well as non-transparency for observers.

We believe that the fiscal mechanism for regulating the investment development of the national economy is based on two types of informal rules:

1. Informal rules related to historical, national and other features that exist in a particular country. They are formed under the influence of traditions, customs, habits, way of thinking, psychology, mentality of its population, entrepreneurs, public sector employees (external institutions). Thus, the mental determinants of Ukrainian society include: individualism, the predominance of personal interests over public ones, patience, paternalism, materialism, savings, diligence, anti-authoritarianism, anti-oligarchism, antistatism, the desire to enrich, the tendency to imitate.

2. Informal rules specific to the fiscal sphere, reflecting the features of the fiscal mechanism for regulating the investment development of the national economy (internal institutions). At present, informal institutions have taken root in the fiscal sphere, focused 
primarily on the realization of narrow group of private economic interests (speculation, money laundering, corruption and its forms: bribery, fraud, stealing, embezzlement, extortion, nepotism, abuse, lobbying, etc.). At the same time, there are other universal informal institutions for society, including tax evasion, smuggling, the "shadow" economy, and so on. These informal institutions are not able to create such an order and rules that can ensure the realization of the fiscal interest of the state and at the same time create conditions for investment development of the national economy.

At the regulatory level of the institutional structure of the fiscal mechanism for regulating the investment development of the national economy are situated the formal rules based on strict regulations and instructions, which are enshrined in law. Formal rules are legal norms that exist in the form of official texts or agreements certified by a third party, in the role of guarantors of which are individuals, government officials who specialize in this function. Such rules are purposefully created, easily fixed in writing and explicitly act as limiters on the set of alternatives for individuals. Agapova (2006, p. 14) naturally assumes that such rules are an integral attribute of the state, which ensures their protection.

Formal rules are characterized by universality, codification, publicity, validity, transparency, clarity, intelligibility and the presence of coercion. The advantages of formal rules include, first, the formalization of rules allows individuals to save on information costs, makes clearer the sanctions for violating these rules, eliminates their inherent contradictions. Secondly, formal rules through government intervention help to solve the problem of ticketlessness, which arises when an individual consciously does not want to pay for the public good, waiting to receive benefits without any payment. Third, formal rules can counteract discrimination by creating an atmosphere of trust and allowing any agent to enter the market freely. Among the shortcomings of formal rules Kosovych (2018) singles out:

legal omissions, legal defaults, non-compliance of legal norms, inconsistency of legal provisions with the principles of law and doctrinal approaches to the theory of law, unreasonable partial certainty, lack of implementation mechanism, non-uniform content of the same legal terms, used in various regulations, non-compliance with the requirement that when adopting new laws or amending existing laws it is not allowed to narrow the content and scope of existing rights and freedoms (p. 185).

In our opinion, the fiscal mechanism for regulating the investment development of the national economy is based on two types of formal rules:

1. Formal rules in the form of regulations that generally relate to the formation and use of financial resources of the budget and the implementation of fiscal policy (general rules). Thus, in Ukraine such regulations include:

1) The Constitution of Ukraine (constitutional norms on the obligation to pay taxes and file tax returns) (Article 67); on the conduct of fiscal policy by the Government (Article 116) and local authorities (Article 119, Article 138, Article 143); on powers of the Parliament on budgetary issues (Article 85); on the construction of the budget system of Ukraine (Article 95); on the organization of the budget process (Articles 96-98); on the budget financing of the judiciary (Article 130, Article 148);

2) codified laws (Budget Code of Ukraine, Tax Code of Ukraine, Customs Code of Ukraine);

3) current laws ("On the State Budget of Ukraine for the relevant year", "On local self- 
government in Ukraine", "On compulsory state pension insurance", "On compulsory state social insurance", "On compulsory state social insurance in case of unemployment", etc.);

4) international regulations (agreements (conventions) with other countries on the avoidance of double taxation, agreements with other countries (foreign banks, international financial organizations) on lending, agreements with other countries (international financial organizations) on the provision of grant assistance, etc.);

5) bylaws (decrees of the President of Ukraine; resolutions of the Cabinet of Ministers of Ukraine; orders of the Ministry of Finance of Ukraine; orders of the State Tax Service, the State Customs Service of Ukraine, the State Treasury Service of Ukraine and other fiscal bodies operating in Ukraine before their creation; regulations of other central executive bodies authorized in the relevant areas of government, in particular in the fiscal sphere).

2. Formal institutions in the form of regulations restricting the formation and use of financial resources of the budget and the implementation of fiscal policy (special (fiscal) rules). Berta and Tóth (2017, p.10-11) interpret fiscal rules as permanent constraints on fiscal policy, which are usually determined in terms of overall fiscal efficiency indicators. Therefore, fiscal rules should be enshrined in law in the form of legal norms, budget procedures or digital budget targets.

Fiscal rules should prevent pro-cyclical fiscal measures in the short term, reduce budget imbalances, control the growth of public debt and strengthen the positive impact of fiscal policy on the investment development of the national economy in the long term. In addition, they should ensure macroeconomic stability, increase confidence in state and local authorities, and minimize negative externalities in the case of different administrative levels and the international community.

Usually in world practice there are four types of fiscal rules, the essence of which, their advantages and disadvantages we have summarized and reflected in table 1.

A number of scholars divide fiscal rules into two types - numerical and procedural ones (Berganza, 2012, p. 11; Sharma and Strauss, 2013, p. 10).

Numerical fiscal rules (signaling changes in fiscal sustainability) are based on numerical benchmarks applied to public debt and / or budget indicators at different levels of government. The most well-known fiscal rule of this type is the "golden rule", which stipulates that government borrowing should be directed exclusively to capital expenditures (investments) and not to current expenditures (consumption). Such fiscal rules may also include borrowing rules (for example, a ban on financing the budget deficit by the central bank). In particular, in Ukraine, the Budget Code stipulates that "the source of budget funding may not be the emission funds of the National Bank of Ukraine" (Article 15). In addition, Ukraine has debt and balancing numerical fiscal rules. Thus, the Budget Code of Ukraine states that "determined by the Budget Declaration, the state budget deficit indicator for each year of the medium term may not exceed 3\% of the projected nominal GDP of Ukraine for the year" (Article 14), as well as "the total public debt and the debt guaranteed by the state at the end of the budget period may not exceed $60 \%$ of the annual nominal volume of Ukraine's GDP” (Article 18).

Procedural fiscal rules (allowing fiscal policy to respond acyclically or anticyclically to changing macroeconomic circumstances) define the principles and related practices of transparency and accountability that should guide the development and implementation 
of fiscal policy. These fiscal rules may include both general procedures for shaping fiscal policy and procedures that help ensure that policy rules are actually enforced in order to establish good practice, increase predictability, and increase the transparency of the budget process. Typical procedural fiscal rules include: a "hierarchical" budgeting process; requirements for transparency in the budget document; clear rules for amending the formulation and approval of the budget. Thus, in the Budget Code of Ukraine in Art. 20 is outlined the hierarchical procedure for budgeting by program-target method; in Art. 27 is defined the procedure for submission and consideration of bills affecting budget indicators and the implementation of such laws; in Art. 28 are highlighted the requirements for the availability of information about the budget.

Thus, the design of fiscal rules usually involves a combination of controlled budget parameters, and their implementation provides a mandatory development of a system of control over compliance with these rules. The introduction of fiscal rules in the fiscal mechanism of investment development of the national economy is the latest trend in international practice, and their effectiveness as a tool to achieve fiscal policy goals is quite tangible and proven, based on the empirical experience of the world.

At the organizational level of the institutional structure of the fiscal mechanism for regulating the investment development of the national economy are organizations that, according to North (1990), consist of a group of individuals linked by a common desire to achieve certain goals, and include political bodies (political parties, parliament, local councils, regulatory agencies), economic bodies (firms, trade unions, family farms, cooperatives), public bodies (churches, clubs, sports associations) and educational bodies (schools, universities, vocational training centers) (p. 5). Based on the above and considering that the term "fiscal" means serving the interests of the treasury (fiscal interests), the organizations (institutions) of the fiscal mechanism for regulating the investment development of the national economy include bodies and institutions that ensure formal and informal rules implementation in the fiscal sphere and influence on the process of formation, distribution and use of financial resources of the budget in order to implement fiscal policy aimed at changes in the national economy due to the realization of investment activities.

Table 1: Characteristics of fiscal rules

\begin{tabular}{|l|l|l|l|}
\hline Type & Characteristics & Advantages & Disadvantages \\
\hline Debt rules & $\begin{array}{l}\text { set the nominal size or } \\
\text { target level of public } \\
\text { debt to GDP }\end{array}$ & $\begin{array}{l}\text { ease of interpretation; } \\
\text { direct link to fiscal } \\
\text { sustainability; relative ease } \\
\text { of management }\end{array}$ & $\begin{array}{l}\text { uncertainty about the optimal } \\
\text { value of public debt; lack of } \\
\text { flexibility due to too pro- } \\
\text { cyclical response to cyclical } \\
\text { fluctuations in the economy; } \\
\text { preventing the operation of } \\
\text { automatic fiscal policy } \\
\text { stabilizers; significant impact of } \\
\text { macroeconomic factors that } \\
\text { are not controlled by fiscal } \\
\text { policy, which necessitates } \\
\text { significant financial } \\
\text { adjustments }\end{array}$ \\
\hline
\end{tabular}




\begin{tabular}{|c|c|c|c|}
\hline Type & Characteristics & Advantages & Disadvantages \\
\hline $\begin{array}{l}\text { Budget } \\
\text { balance } \\
\text { rules }\end{array}$ & $\begin{array}{l}\text { limit the absolute level } \\
\text { of the budget deficit } \\
\text { or determine the } \\
\text { maximum level of the } \\
\text { budget deficit relative } \\
\text { to GDP }\end{array}$ & $\begin{array}{l}\text { insignificant influence of } \\
\text { macroeconomic factors } \\
\text { that are not controlled by } \\
\text { fiscal policy; considerable } \\
\text { flexibility due to } \\
\text { independence from } \\
\text { economic cycles and } \\
\text { temporary budget items; } \\
\text { enabling action of } \\
\text { automatic fiscal policy } \\
\text { stabilizers }\end{array}$ & $\begin{array}{l}\text { the probability of public debt } \\
\text { growth due to extra-budgetary } \\
\text { items; complex calculation } \\
\text { methodology }\end{array}$ \\
\hline $\begin{array}{l}\text { Expenditure } \\
\text { rules }\end{array}$ & $\begin{array}{l}\text { limit total, primary or } \\
\text { current expenditures } \\
\text { in absolute terms or in } \\
\text { a percentage to GDP, } \\
\text { and sometimes } \\
\text { regulate the rate of } \\
\text { their real (or nominal) } \\
\text { growth }\end{array}$ & $\begin{array}{l}\text { ease of interpretation; } \\
\text { significant flexibility due to } \\
\text { independence from } \\
\text { economic cycles; the ability } \\
\text { to control the size of the } \\
\text { general government } \\
\text { management sector by } \\
\text { regulating the level of } \\
\text { redistribution; enabling } \\
\text { action of automatic fiscal } \\
\text { policy stabilizers }\end{array}$ & $\begin{array}{l}\text { complex calculation } \\
\text { methodology; inability to } \\
\text { directly influence the fiscal } \\
\text { balance or public debt }\end{array}$ \\
\hline $\begin{array}{l}\text { Income } \\
\text { rules }\end{array}$ & $\begin{array}{l}\text { set the maximum } \\
\text { possible or minimum } \\
\text { allowable level of } \\
\text { budget revenues, } \\
\text { which should } \\
\text { guarantee an } \\
\text { acceptable state of the } \\
\text { tax burden or, } \\
\text { conversely, increase } \\
\text { the scale of budget } \\
\text { revenues }\end{array}$ & $\begin{array}{l}\text { the possibility of increasing } \\
\text { the efficiency of tax } \\
\text { collection, improving the } \\
\text { quality of tax } \\
\text { administration and } \\
\text { reducing tax evasion and } \\
\text { the shadow economy; } \\
\text { enabling realization of } \\
\text { expansionist and restrictive } \\
\text { fiscal policies }\end{array}$ & $\begin{array}{l}\text { inability to ensure or improve } \\
\text { the sustainability of fiscal } \\
\text { policy; lack of flexibility due to } \\
\text { too pro-cyclical response to } \\
\text { cyclical fluctuations in the } \\
\text { economy; preventing the } \\
\text { operation of automatic fiscal } \\
\text { policy stabilizers }\end{array}$ \\
\hline
\end{tabular}

Source: Compiled by the authors on the basis of papers (Berta, Tóth, 2017, pp.14-17; Vynnychenko, 2017, p.82).

Among such organizations we single out:

1. Strategic regulatory authorities, which are the legislative and executive authorities that determine the strategic priorities of fiscal policy and ensure the approval of relevant budgets. Such bodies in Ukraine include: the President of Ukraine, the Verkhovna Rada of Ukraine, the Cabinet of Ministers of Ukraine, local councils of people's deputies, executive bodies of local councils, the Pension Fund of Ukraine, the National Bank of Ukraine, the Ministry of Finance of Ukraine. These bodies directly shape fiscal policy and organize its implementation.

2. Tactical regulatory authorities, which are executive bodies that implement fiscal policy and ensure the planning and implementation of relevant budgets. Such bodies in Ukraine include: the Accounting Chamber of Ukraine, the State Tax Service of Ukraine, the State Customs Service of Ukraine, the State Treasury Service of Ukraine, the Financial Control 
Office, the Social Insurance Fund of Ukraine, the Fund of Compulsory State Social Insurance of Ukraine in case of unemployment. These bodies do not directly formulate fiscal policy, but ensure its implementation and may make proposals for its formation or adjustment.

3. Managers and recipients of budget funds, which are budget institutions, business entities, public or other organizations that receive budget funds. These entities operate under the direct influence of fiscal policy, although they do not participate in its development and implementation.

4. Payers of taxes, fees, payments to the budget, which, on the one hand, fill the revenue side of budgets, and, on the other - can receive payments (in the form of wages, transfers) from budgets. These entities operate under the indirect influence of fiscal policy, although they do not participate directly in its development and implementation.

5. Public councils at central executive bodies, which are temporary advisory bodies formed to facilitate public participation in the formation and implementation of fiscal policy. Examples of such organizations in Ukraine are the Public Council under the Ministry of Finance of Ukraine, the Public Council under the State Tax Service of Ukraine, the Public Council under the State Customs Service of Ukraine, the Public Council under the State Treasury Service of Ukraine, the Public Council under the Pension Fund of Ukraine.

It should be noted that public councils in Ukraine act like independent fiscal organizations in developed countries, which are independent state organizations with the authority to critically evaluate and in some cases provide non-partisan advice on fiscal policy and its effectiveness. Although fiscal decisions are ultimately the responsibility of democratically elected officials, independent fiscal organizations serve (often in conjunction with reliable fiscal rules) to promote reasonable fiscal policies and the sustainability of public finances. According to von Trapp, Lienert and Wehner (2016, pp. 17-18), the main functions of these organizations, such as assessing or preparing macroeconomic and fiscal forecasts and monitoring and evaluating of fiscal plans and results, can help resolve conflicts over budget expenditures and deficits. In world practice, independent fiscal organizations are created in the form of fiscal councils (UK, Sweden, Ireland, Austria, Belgium, Denmark and France) (statutory executive bodies or autonomous bodies that may have double lines of accountability to the legislative and executive branches), parliamentary budget bureaus (Australia, Canada, Italy, Korea, Mexico, USA) (with greater emphasis on promoting parliamentary control over the budget and supporting the work of the main budget committee of the parliament), or autonomous units included in the national audit institution (France, Finland) (von Trapp, Lienert, Wehner, 2016, p. 13).

6. International organizations that influence the fiscal policy of the state. Thus, Ukraine is a member of the following international organizations: the Global Forum on Transparency and Information Exchange for Tax Purposes, the Center for Advanced Training in Finance, the German Society for International Cooperation, the International Monetary Fund, the World Bank, the European Investment Bank, the European Bank for Reconstruction and Development, etc. These organizations have an indirect influence on the formation of fiscal policy, but do not participate in its implementation.

At the resource-technological level of the institutional structure of the fiscal mechanism for regulating the investment development of the national economy are situated financial resources, at the formation, distribution and use of which is aimed the influence of formal 
and informal rules and institutions through various fiscal technologies. Fiscal technologies include:

1) forecasting and planning technologies that allow to determine the volume of redistribution of GDP through the budget and calculate budget indicators for a specific period;

2) accounting technologies, which provide for registration and accounting of taxpayers, managers and recipients of budget funds, accounting of budget revenues and expenditures, reception and processing of budget and tax reporting;

3) analytical technologies, including analysis of the state of budget indicators and possible changes in the uniformity and adequacy of the budget;

4) mass-explanatory technologies, which allow to establish partnership relations between the state and society on the formation of budget and tax culture;

5) control and verification technologies aimed at ensuring timely and complete receipt of taxes, fees and other payments to budgets, as well as their targeted and effective use;

6) information technologies, which provide for the timely exchange of information between the participants of fiscal relations.

Thus, the institutional structure of the fiscal mechanism provides a coordinated interaction of economic agents, aimed at realizing both short-term interests and long-term goals of regulating the investment development of the national economy. The state plays a leading role in the institutional structure of the fiscal mechanism for regulating the investment development of the national economy. Thereby, the state, on the one hand, acts as a source of formal rules and the founder of institutions, and on the other - as an economic agent, has its own interests, but is obliged to act as a representative of society, forming public policy in the relevant field. In addition, the state has fiscal interests associated with the fullest formation of its budget, but the investment interests of society usually go against the fiscal interests of the state, which leads to the formation of appropriate fiscal policies aimed at regulating the investment development of the national economy.

\section{Conclusions}

The study found that the institutional structure of the fiscal mechanism for regulating the investment development of the national economy is a set of interrelated formal and informal rules, as well as organizations that ensure their implementation, which together influence the formation, distribution and use of financial resources for the purpose of fiscal policy implementation, aimed at changes in the national economy, due to the realization of investment activities, and, as a result, benefits are obtained and the interests of all subjects of economic relations are satisfied, as well as a new qualitative state of the economy emerges.

The institutional structure of the fiscal mechanism for regulating the investment development of the national economy is four-level: at the cognitive level there are informal rules, at the regulatory level are formal rules, at the organizational level are organizations (institutions), at the resource-technological level are financial resources, at the formation, distribution and the use of which is aimed the influence of formal and informal rules and institutions, thanks to a variety of fiscal technologies.

At the present stage of Ukraine's development, the institutional structure of the fiscal 
mechanism is formed, but its characteristics do not sufficiently meet the characteristics, resources and objectives of regulating the investment development of the national economy. Currently, all institutions need significant improvement and transformation to stimulate investment processes. Moreover, in the conditions of unstable geopolitical situation and significant resource constraints, it is important to find those key links and key directions of development of the institutional structure of the fiscal mechanism, which can be factors in intensifying investment activity in the country. Therefore, this article, focusing on institutions, can be seen as an attempt to develop a discussion between economists of different schools to create a theoretical basis for developing practical recommendations for the development of the institutional structure of the fiscal mechanism for regulating investment development of the national economy.

\section{References:}

Agapova, I. I. (2006). Institutional economy. Moscow: Economist.

Aoki, M. (2000). What are Institutions? How Should We Approach Them? Stanford, CA: Stanford University. Ayres, C. E. (1944). The Theory of Economic Progress. New York, NY: The University of North Carolina Press. Berganza, J. C. (2012). Fiscal rules in Latin America: a survey. Madrid: Banco de España.

Berta, D. and Tóth, Cs. G. (2017). Fiscal rules. Budapest: Magyar Nemzeti Bank.

Borovskaja, L. V. (2018). Institutional environment and features of its formation as a result of institutional changes. Bulletin of Voronezh state university. Series: Economy and management, 4, 5-12.

Bowles, S. (2004). Microeconomics: Behavior, Institutions, and Evolution. New York, NY: Russell Sage Foundation.

Brousseau, E. and Glachant, J.-M. (2008). New Institutional Economics A Guidebook. New York, NY: Cambridge University Press.

Cherkas, S. V. (2010). The main functions of the institutions. Culture of the peoples of the Black Sea region, 196(1), 225-228.

Clark, J. M. (1923). Studies in the Economics of Overhead Costs. Chicago, IL: University of Chicago Press.

Coase, R. H. (1992). The Institutional Structure of Production. University of Cbicago Law Occasional Paper, 28, 1 16.

Commons, J. R. (1931). Institutional Economics. American Economic Review, 21, 648-657.

Dequech, D. (2013). Economic Institutions: explanations for conformity and room for deviation. Journal of Institutional Economics, 9(1), 81-108.

Eggertsson, T. (2003). Economic behavior and institutions. New York, NY: Cambridge University Press.

Fourastié, J. (1960). The Causes of Wealth. (T. Caplow, Trans. \& Ed.). Glencoe, IL: The Free Press.

Galbraith, J. K. (1967). The New Industrial State. Boston, MA: Houghton Mifflin Company.

Greif, A. and Kingston, C. (2011). Institutions: Rules or Equilibria? In N. Schofield and G. Caballero (Ed.). Political Economy of Institutions, Democracy and Voting (pp.13-43). Berlin; Heidelberg: SpringerVerlag.

Hamilton, W. H. (1919). The institutional approach to economic theory. American Economic Review, 9(1), 309318.

Heilbroner, R. L. (1953). The Worldly Philosophers: The Lives, Times, and Ideas of the Great Economic Thinkers. New York, NY: Simon and Schuster.

Hindriks, F. and Guala, F. (2015). Institutions, rules, and equilibria: a unified theory. Journal of Institutional Economics, 11(3), 459-480.

Hodgson, G. M. (2006). What Are Institutions? Journal of Economic Issues, XL(1), 1-25.

Hodgson, G. M. (2009). Institutional Economics into the Twenty-First Century. Studi e Note di Economia, 14(1), 03-26.

Knight, F. H. (1921). Risk, Uncertainty, and Profit. Boston, MA \& New York, NY: Houghton Mifflin Company.

Kolodko, G. W. (2006). Institutions, Policies and Economic Development. Helsinki: Helsinki World Institute for Development Economics Research.

Kosovych, V. (2018). Hidden (latent) shortcomings of normative legal acts of Ukraine: general theoretical characteristics. Public law, 2, 184-191. 
Kovalenko, B. (2011). Metodological features of modern institutional economics. Social and Natural Sciences Journal. 3, 55-61.

Martjukova, E. G. (2012). The role of institutions in regulating the opportunistic behavior of economic agents. Collection of scientific papers SW orld, 18(1), 88-94.

Melnychuk, O. S. et al. (Eds.). (1974). Dictionary of foreign words. Kyiv: The main edition of the Ukrainian Soviet Encyclopedia of the Academy of Sciences of the Ukrainian SSR.

Menger, C. (1985). Investigations into the method of the social sciences with special reference to economics. (L. Schneider, Ed., F. J. Nock, Trans.). New York, NY: University Press.

Mitchell, W. C. (1910). The rationality of economic activity. The Journal of Political Economy, 18(3), 197-216.

Myrdal, G. (1957). Economic Theory and Underdeveloped Regions. London: Gerald Duckworth.

North, D. (1990). Institutions, institutional change and economic performance. New York, NY: Cambridge University Press.

Olsen, J. P. (2007). Understanding Institutions and Logics of Appropriateness: Introductory Essay. Oslo: ARENA Centre for European Studies.

Ostrom, E. (1990). Governing the Commons: The Evolution of Institutions for Collective Action. Cambridge: Cambridge University Press.

Panov, V. P. (2011). Institutions, Identities, Practices: A Theoretical Model of the Political Order. Moscow: Russian Political Encyclopedia (ROSSPEN).

Parkinson, D. and Noble, J. (Eds.) (2008). Oxford Business English Dictionary for Learners of English. Oxrord: University Press.

Perroux F. (1960). Économie et Société. Contrainte - Échange - Don. Paris: Presses Universitaires de France.

Rutherford, M. (1994). Institutions in economics. The old and the new institutionalism. New York, NY: Cambridge University Press.

Samuelson, P. A. and Nordhaus, W. D. (2010). Economics. 19th ed. New York, NY: McGraw-Hill/Irwin.

Schmoller, G. von. (1900). Grundriss der Allgemeinen Volkswir.tschaftslehre. Munich and Leipzig: Duncker and Humblot.

Searle, J. R. (2005). What is an institution? Journal of Institutional Economics, 1, 1-22.

Shapkin, V. V. (2011). Methodological foundations of institutionalism. Problems of the modern economy, 2, 58-62.

Sharma, N. and Strauss, T. (2013). Special fiscal institutions for resource-rich developing economies. The state of the debate and implications for policy and practice. London: Overseas Development Institute.

Stiglitz, J. E. and Walsh, C. E. (2006). Economics. 4th ed. New York, NY: W. W. Norton \& Company.

Trapp, L. von, Lienert, I. and Wehner, J. (2016). Principles for independent fiscal institutions and case studies. OECD Journal on Budgeting, 15(2), 9-24.

Vahtina, M. A. (2005). Institutionalism as a reflection of the sociocultural approach in economics. Bulletin of the Saratov State Social and Economic University, 11, 23-25.

Vanberg, V. (1994). Rules and Choice in Economics. Essays in Constitutional Political Economy. London: Routledge.

Veblen, T. (1922). The Theory Of The Leisure Class An Economic Study of Institutions. New York, NY: B. W. HUEBSCH.

Vynnychenko, N. V. (2017). Assessment of the impact of fiscal rules on the budget process. Scientific Bulletin of the International Humanities University. Series: Economics and Management, 27(2), 93-96.

Williamson, O. E. (1975). Markets and Hierarchies: Analysis and Antitrust Implications, A Study in the Economics of Internal Organization. New York, NY: Free Press.

Zaslavskaja, T. I. (2004). Contemporary Russian society. Social mechanism of transformation. Moscow: Science. 